\title{
Story in the Qur'an and Its Relevance in Early Childhood Education
}

\author{
$\underline{\text { Ali Imran Sinaga }}{ }^{1}$, Afrahul Fadhilah Daulay ${ }^{2}$, Rosmawati Lubis $^{3}$ \\ 1.2,3Faculty of Tarbiyah and Teacher Training, Universitas Islam Negeri Sumatera Utara, Indonesia \\ Email: rosmawati.lubis1969@gmail.com
}

\begin{abstract}
The purpose of this study is to find out: the disclosure of stories in the Qur'an, and the relevance of the stories in the Qur'an to early childhood education. The research method used is qualitative. Data collection techniques carried out by documentation and interviews. Data collection procedures are carried out with the stages of data collection, data reduction, data presentation, and drawing conclusions. Checking the validity of the data is carried out with four criteria, namely credibility, transferability, dependability, and confirmability. Research findings show the story in the Qur'an means the stories or news of the Qur'an about events or events that befell the people or previous people, both involving human nations and the nations of the jinn and angels, even nations of the animal group who acts like a human. The story in the Qur'an is the best story, it is a true story and contains a lot of "ibrah (lessons) for people who think deeply, so it must be thought of. The story in the Qur'an has very close relevance to Islamic education. Such a close relationship is marked by the existence of stories in the Qur'an as a model or form of Islamic education that is able to inspire the birth of several principles and theories of Islamic education.

Keywords: story in the Qur'an; early childhood education
\end{abstract}

\section{Introduction}

The Qur'anic content about history or stories is called the Qur'anic story. Even the verses that talk about the story are far more than the verses that talk about the law. This gives a signal that the Qur'an is very concerned with the problem of the story, which indeed contains many lessons (ibrah).

Therefore the story in the Qur'an has its own meaning when compared to the contents of other ingredients. So it is necessary for us as Muslims to know the contents of the stories in the Qur'an so that we can take lessons. Al-Qur'an besides containing the teachings of aqidah (belief), sharia (Islamic law), morality, promises and threats, philosophy, signs, also contains stories, especially stories about the prophets and their people before the prophet Muhammad and other people are destroyed because of their pride.

\section{Review of Literatures}

The story comes from the word al-qashshu which means to look for or follow in the footsteps (Al-Qaththan, 2005: 386). The story is also in Arabic, namely qissah, which is an articulate (Ibn al-Manz, 342). Qissas meaning with qasas, masdar form of qassa. This word is rooted in the letters qaf and sad, with the main meaning following something (Abu alHusayn, 1998: 11). From the two letters the verb qassa is formed which can be interpreted by following in sequence or following in his footsteps and can also mean to cut. Lexically, besides meaning to follow in the footsteps, qissah can also mean al-hadis (stories), which is one part or branch of literature (Fath Ridwan: 100). These two understandings are not contradictory. Because, to find out the whole story, it must be traced, tracked and followed as whole. 
Thus it needs to be done, especially for true stories that occur or stories that are historically patterned. Search for these stories can be done from the top down, or vice versa. In addition, the story is not often cut into specific episodes.

Qashash means sequential news. The Word of God: "Truly this is the true message). (Al Imran: 62). Qashash Al-quran is the preaching of the Qur'an about matters of the past people, prophecy (prophecy) before and the events that occurred. Al-Qur'an contains a lot of information about past events, the history of nations, the state of countries and the legacy or footprint of the people. He tells all their circumstances in an interesting and charming way (Al-Qaththan, 2005: 387).

Thus, that the story is a literary work that depicts certain events and figures, arranged based on imagination or reality, or a combination of both, using enchanting language. In the Qur'an, although the word qissah is not found, but the word originates from qasssa with all sorts of the shape was found thirty times (al Baqiy, 1991: 693). From the whole verse it appears that the three meanings of qasas as mentioned above are in accordance with the meaning given by the Qur'an.

There are 3 kinds of stories in the Qur'an:

1. The stories of the Prophets (qashash al-anbiya). The Koran contains stories about the da'wah of the prophets and the miracles of the Apostles and the attitude of the people who oppose and proselytizing and its development, in addition to explaining the consequences faced by the believers and deniers, such as the story of the Prophet Lut, Ibrahim, Musa, Harun, Isa, Muhammad SAW and others,.

2. Stories that are linked to events that have happened and those who cannot be confirmed prophetic, such as the story of people who went from his hometown, which numbered in the thousands because of fear of death such as the story of Thalut and Jalut, two sons of Adam, AShhab al-Kahfi, Zulkarnain, Qorun and Ashhabus Sabti, Maryam, Ashhab alUkhdud, Ashhab al-Fil and others.

3. Stories relating to events that took place in the time of the Prophet Rasullullah, such as the battle of Badr and Uhud which are explained in the Surah Al-Imran, the Taubah War, the Ahzab war as explained in the Surah Al-Ahzab and the Hijrah and Isra 'and others (AshShiddieqy, 2017: 180).

Especially for the story in the Qur'an, dialogue does not only occur between fellow human beings, but occurs between other story figures, such as:

1. Dialogue between God and angels. For example, the story of Adam as mentioned in QS. al-Baqarah (2): 30-32.

2. Dialogue between Allah and the devil. For example, Adam's story is as contained in the QS. al-A'raf (7): 12-18.

3. Dialogue between God and humans. For example, the story of an adventurer whom God has killed hundreds of years. This story is found in QS. al-Baqarah (2): 259 (Ibn Kasir, 1991: 297) similar also appears in the story of the Prophet Ibrahim as contained in QS.alBaqarah (2): 260. Dialogue between humans and angels. For example, the story of Ibrahim in QS. Al-Zariyat (31): 24-30.

4. Dialogue between humans and animals of this type of dialogue only takes place in the story of Solomon. This can be seen in QS. al-Naml (27): 20-28.

5. Dialogue between human beings For example, dialogue between Prophet Ibrahim and his father. This can be seen in QS. Maryam (19): 41-48. 
The stories in the Qur'an have many benefits as follows: Among them:

1. Explain the principles of da'wah towards God and explain the main points of Shari'a brought by the Prophets.

2. Strengthening the hearts of the Prophet and the hearts of the people of Muhammad in religion with Allah's religion and strengthening the beliefs of the believers about the coming of God's help and the destruction of evil.

3. Preserve the efforts of the Prophets and the statement that the Prophets were true.

4. Demonstrate the truth of the prophet Muhammad, in his da'wah by being able to explain the conditions of the past people.

5. Revealing the lies of the book expert who has hidden the contents of the book that is still pure.

6. Attract the attention of those given the lesson.

The stories contained in the Qur'an should be given early on to children. This is because children are the hope of the future and the successors of survival and continuation of life. Therefore the task of parents is to educate and direct their children according to their talents. Because in early childhood full of great curiosity, they desire to become an individual who has adequate abilities in accordance with the level of maturity. If from an early age, a child gets a good chance, then later he will be a person of morality and knowledge

\section{Research Methods}

The research method used is qualitative. Data collection techniques carried out by documentation and interviews. Data collection procedures are carried out with the stages of data collection, data reduction, data presentation, and drawing conclusions. Checking the validity of the data is carried out with four criteria, namely credibility, transferability, dependability, and confirmability.

\section{Discussion}

The narration of the stories of the Qur'an is filled with educational content for humans, especially readers and listeners. These stories form part of an effective educational method for the formation of a soul who is condemned to Allah SWT. Because it was confirmed by Allah SWT "faqshush alwashash la 'allahum yatafakkarun" then tell stories so they think.

If we examine further, most of the verses of the Koran that contained a load of stories down when the prophet Muhammad SAW in the city of Mecca. That period the priority of Rasullullah's da'wah was more directed at planting the creed and monotheism. This gives a signal that the stories are very influential in the effort to educate someone who originally did not have the belief of monotheism to become a servant of Allah who is tawheed.

In addition, in the Mecca period, the prophet Muhammad also made a lot of efforts to instill morality from the habits of unscrupulous people. Giving examples of the stories of previous people along with the consequences experienced for those who oppose God's commands and behave unfavorably indirectly knocked the hearts of people who contemplate the wisdom behind the story. The story becomes a gentle means to change the mistakes and disbelief of a community, by not directly patronizing or blaming them.

In the world of education, education patterns that only use the lecture method in a moological manner are certainly very boring for students, especially among beginner students 
in early childhood. An educator must be able to provide a variety of learning methods by inserting various stories and stories that are relevant to the competency and learning material.

We have seen so many film screenings both on the big screen and the screen, the screening of soap operas, tater, traditional arts, puppets and ketoprak is an inseparable part of the form of stories or stories that are packaged in various media.

All of these media stories certainly have an influence on the attitude (affective) and the mentality of the viewers and listeners. This statement shows how important stories are to human life. Therefore, it is very appropriate if in the Qur'an there are stories or stories that can be used as a reference for human life.

The world of education is essentially an effort to explain the results of the experimentation of a story of human life throughout history. In education positive stories are used as references. Taking this exemplary story at the same time has similarities with the Qur'anic mission of bringing humans to the figure of a perfect person (al insan al kamil) who has a noble character (al akhlak al karimah).

Neither is in harmony with the mission of Rosullullah SAW who was sent to bring mercy to the universe. A good education is what will also bring people and life in this world to prosper physically and mentally, a life that is filled with the attitude of mutual respect between fellow humans and even with other creatures.

The phenomenon of global warning (global warming) which currently afflicts the world community is one of the cases of the still distant human life in the era of globalization and industrialization from true welfare and grace. Especially with the still many battles and bloodshed on earth. Therefore, the progress of science and technology which is not based on noble character is not an educational result, but instead will deliver humans to the abyss of destruction as it has been told in the Qur'an over previous nations, such as the Thamud, Ad and others.

Stories also become an effective media to give warnings to students not to fall into various immoralities or crimes. With a story or the story of students will get a touch of values that will affect the character..

\section{Conclusion}

The conclusions of this study are:

1. The story in the Qur'an means the stories or news of the Qur'an about events or events that befell the people or previous people, both involving human nations and the nations of the Jinn and angels, even a nation of animals who act like humans. The story in the Qur'an is the best story, it is a true story and contains a lot of "ibrah (lessons) for people who think deeply, so it must be thought of. Stories in the Qur'an are diverse. The diversity of the story can be seen in the elements of its construction as well as its fascinating method of statement and systematic discussion. The story in the Qur'an basically aims to strengthen the faith of the Prophet Muhammad and his people, so that they will not be shaken despite facing various problems. In addition, the story in the Qur'an also aims to illustrate Muhammad and his people about various aspects of life and their problems, even though the path that must be taken to overcome them. These goals, in general, are inseparable from the function or existence of the Qur'an as a guide, and in particular are inseparable 
from the function or existence of stories as' ibrah, mau'izah and zikra for people who believe.

2. Stories in Al-Qur'an has very close relevance with Islamic education. Such a close relationship is marked by the existence of stories in the Qur'an as a model or form of Islamic education that is able to inspire the birth of several principles and theories of Islamic education. Besides that, the relationship between stories in the Qur'an and Islamic education can also be seen from the existence of the Qur'anic

3. story as an effective method of conveying or transforming educational material, in fact, it itself can be used as Islamic education material.

Recommendations that can be given are:

1. This research is a study of verses of the Qur'an, especially those containing stories, both in the form of story expressions themselves, and in the form of stories that describe an event in relation to Islamic education. To sharpen this, research on terms that are meaningful with stories such as, jadis, khabar, naba 'which did not receive much attention in this study, needs to be explored more.

2. Research on stories in the Qur'an and their relation to education This Islam, in particular, is still limited to the story of Adam and Joseph. Therefore, it is still necessary to do research on other stories with the same model, so that other educational theories will be obtained that are not found in these two stories. In addition, this research is still general in terms of aspects or elements of Islamic education. Therefore, more specific research is needed, for example educators in the perspective of stories in the Qur'an or material, even curriculum in the perspective of stories in the Qur'an.

3. This research will lead Muslims to conduct deeper studies of Al-Qur'an as Allah commands, especially about the story in the Qur'an, in an effort to enrich the Islamic treasures, especially in the fields of educational theories, as well as in the field of literature, because the story is basically part of both. Thus, the existence of the Qur'an as a guide can be applied and implemented in daily life. Besides that, this will increase and strengthen the faith of Muslims in the authenticity and truth of the Qur'an which is not consumed by time.

\section{References}

'Abd al-Aziz, Saleh dan 'Abd al-'Azis 'Abd al-Majid. Al-Tarbiyat wa Turug al-Tadris. Mesir: Dar al-Ma'ārif, 1997.

Abdullah, 'Abd al-Rahman Saleh. Educational Theory A Quranic Outlook.Diterjemahkan oleh Mutammam dengan judul Landasan dan Tujuan Pendidikan Menurut Alquran serta Implementasinya. Bandung: Diponegoro, 1991

Al-Abrasyiy, Muhammad Atiyat. Al-Tarbiyat al-Islamiyat wa Palasifatuha. Mesir: al-Babiy alHalabiy,1976.

Al-Attas, Sayyed Muhammad al-Naquib. The Concep of Education in Islam. Alihbahasa Haidar Bagir dengan judul Konsep Pendidikan Islam Bandung: Mizan, 1996.

Al-Nahlawiy, 'Abd al-Rahman Usul Al-Tarbiyat Al-Islamiyai Wa Asalibuha Fi Al-Bayt alMadrasat Wa Al- Mustama. Alihbahasa Shihabuddin Pendidikan Islam di Rumah, Sekolah dan Masyarakat. Jakarta: Gema Insani Press, 1995.

Arifin, M. Ilmu Pendidikan Islam: Suatu Tinjauan Teoritis dan Praktis BerdasarkanPendekatan Multidisipliner. Jakarta: Bumi Aksara, 1993

Budianti, R., Mardianto, M., and Zulheddi, Z. Implementation of Tikrar Methods in Memorizing Al-Qur'an in Tahfidzul Qur'an Foundation Al-Fawwaz Medan. Budapest International Research and Critics in Linguistics and Education (BirLE) Journal (3): 974-980

Darajat, Zakiah. Ilmu Pendidikan Islam. Jakarta: Bumi Aksara, 1992. 
Ilyas, Asnelly. Mendambakan Anak Shaleh, Prinsip-prinsip Pendidikan Anak Dalam Islam. Bandung: Al Bayan, 1995.

Mursiv, Muhammad Munir. Al-Tarbiyat al-Islamiyat, Usuluha wa Tatawwuruha fi alBilad al'Arabiyah. Mesir: "Alam al-kutub, t. th.

Rahayu,T., Daulay, H., and Zulheddi Z. 2020. Implementation of Al-Qur'an Reading Learning Tartili Method in MAS Sinar Serdang Perbaungan. Budapest International Research and Critics in Linguistics and Education (3): 1021-1032 